\title{
Evaluasi Keragaan Generasi Pertama Selfing Jagung Ketan Lokal
}

\author{
Evaluation of the First Selfing Generation of Local Waxy Corn
}

\author{
Anita Rosliana, Surjono Hadi Sutjahjo* dan Siti Marwiyah \\ Departemen Agronomi dan Hortikultura, Fakultas Pertanian, Institut Pertanian Bogor \\ (Bogor Agricultural University), Jalan Meranti, Kampus IPB Dramaga, Bogor 16680, Indonesia. \\ Telp. \& Faks. 0251-8629353 e-mail: agronipb@indo.net.id \\ *Penulis untuk korespondensi : surjonohadi@yahoo.co.id
}

Disetujui 20 Agustus 2018 / Published online 3 September 2018

\begin{abstract}
Waxy corn has a low productivity. The superiority of local waxy corn has more starch containing amylopectin. Plant breeding activities are needed to improve productivity and character of waxy corn in order to have a sweeter taste. This research is aimed to evaluate some qualitative characters, quantitative characters, and potential prolific character in the SI generation of corn. This research was conducted at Leuwikopo IPB Experimental Station at Dramaga, Bogor from February to June 2017. The experiment was arranged in a randomized completely block design with single factor and three replications. The factor were 16 genotypes and 1 variety of comparison (URI). The results showed that the test genotypes had several quantitative and qualitative characters which different from the other genotypes or check variety URI. There were seven characters with hight heritability of broad meaning and one character with medium heritability of broad meaning. The character of ASI was wide in genetic diversity, high heritability of broad meaning, and negatively correlated with yield component such as ear diameter, number of rows of corn kernels, and weight of ear with cornhusk, so it can be considered as selection criteria. Genotype JLPI2, JWP12-5, dan JWP12-8 have a potential prolific character with number of ear per plant each are 2,55 ears, 2,20 ears, and 2,31 ears. Genotype SD2, JWP12-5, JWP12-3, JWP22-1, and JLP1-6 are the highest agronomic character and yield component.
\end{abstract}

Keywords: corn, heritability, qualitative character, quantitative character

\begin{abstract}
ABSTRAK
Jagung ketan lokal memiliki produktivitas yang rendah. Keutamaan jagung ketan lokal yaitu memiliki pati yang mengandung amilopektin lebih banyak. Kegiatan pemuliaan tanaman diperlukan untuk meningkatkan produktivitas dan memperbaiki karakter jagung ketan agar memiliki rasa lebih manis. Penelitian ini bertujuan untuk melakukan evaluasi beberapa karakter kuantitatif, kualitatif, dan potensi sifat prolifik pada generasi S1 jagung. Penelitian dilaksanakan di Kebun Percobaan Leuwikopo, Dramaga, Bogor pada bulan Februari - Mei 2017. Rancangan percobaan yang digunakan yaitu Rancangan Kelompok Lengkap Teracak (RKLT) faktor tunggal yaitu genotipe dengan tiga ulangan. Faktor perlakuan yaitu genotipe jagung yang terdiri atas 16 genotipe uji dan 1 genotipe pembanding URI. Hasil penelitian menunjukkan bahwa genotipe- genotipe uji jagung ketan memiliki beberapa karakter kuantitatif dan kualitatif yang berbeda dari genotipe- genotipe uji yang lain maupun varietas pembanding URI. Sebanyak tujuh karakter yang diamati memiliki nilai heritabilitas arti luas $\left(\mathrm{h}^{2}{ }_{\mathrm{bs}}\right)$ yang tinggi dan satu karakter memiliki nilai heritabilitas arti luas $\left(\mathrm{h}_{\text {bs }}^{2}\right)$ yang sedang. Karakter ASI memiliki nilai KK dan heritabilitas arti luas yang tinggi serta berkorelasi negatif dengan komponen hasil berupa diameter tongkol, jumlah baris biji, dan bobot tongkol berkelobot sehingga dapat dipertimbangkan sebagai kriteria seleksi. Genotipe JLP1-2, JWP12-5, dan JWP12-8 memiliki potensi sifat prolifik dengan jumlah tongkol per tanaman masing-masing sebanyak 2,55 tongkol, 2,20 tongkol, dan 2,31 tongkol. Genotipe SD2, JWP12-5, JWP12-3, JWP22-1, dan JLP1-6 memiliki karakter agronomi dan komponen hasil yang baik.
\end{abstract}

Kata Kunci: heritabilitas, jagung, karakter kuantitatif, karakter kualitatif 


\section{PENDAHULUAN}

Jagung merupakan komoditas utama dalam pertanian di Indonesia selain padi dan kedelai. Konsumsi nasional rumah tangga terhadap komoditas jagung pada tahun 2014 sebesar 391 ribu ton. Total konsumsi meningkat sebesar 7,63\% dari tahun 2013. Peningkatan tersebut terjadi karena peningkatan konsumsi jagung basah berkulit sebagai substitusi pangan pokok (Chafid et al., 2015). Rata-rata pertumbuhan konsumsi jagung basah berkulit pada tahun 2009 - 2013 sebesar 2,08 \% (Kementan, 2015). Kebutuhan jagung sangat besar dengan berbagai jenis penggunaan.

Indonesia memiliki beragam plasma nutfah jagung lokal. Menurut (Yusran dan Maemunah, 2011) Pulau Sulawesi Tengah memiliki jenis jagung ketan lokal yang beragam. Jagung ketan (waxy corn) termasuk jagung khusus yang mempunyai ciri unik. Endosperma jagung ketan mengandung molekul pati bercabang yang disebut amilopektin (Kopyra et al., 2012). Pati dalam endosperma jagung ketan terdiri atas $25 \%$ bagian amilosa dan $75 \%$ amilopektin (Brewbaker, 2003). Kandungan amilopektin yang tinggi menyebabkan jagung ketan memiliki rasa pulen, gurih, dan membutuhkan waktu tanak lebih lama. Jagung ketan dimanfaatkan segar maupun olahan sebagai pangan lokal yang menjadi makanan ciri khas daerah di Indonesia. Selain itu, jagung ketan dengan keunggulan pati yang tinggi berpotensi sebagai bahan baku pembuatan tepung jagung dan bahan pengental makanan. Daya cerna pati jagung ketan lebih rendah dibandingkan jagung nonketan sehingga cocok untuk dikonsumsi oleh penderita diabetes.

Menurut Sari (2015) Jagung Lombok Putih 1 mempunyai jumlah tongkol banyak (prolifik) dan jagung Walamize Putih 2.2 mempunyai kualitas tongkol paling baik. Worrajinda et al. (2013) menyatakan bahwa sifat prolifik secara signifikan dipengaruhi oleh interaksi antara genetik dengan lingkungan. Sifat prolifik menghasilkan jagung dengan ciri tongkol lebih banyak dalam satu tanaman. Tongkol yang tidak berkembang secara sempurna dapat dimanfaatkan sebagai produk sayuran berupa jagung semi atau baby corn. Jumlah tongkol menjadi strategi yang penting untuk meningkatkan hasil panen jagung.

Produktivitas jagung ketan lokal masih rendah yaitu sebesar 2-2,5 ton ha $^{-1}$ dan tidak tahan terhadap penyakit bulai (Azrai et al., 2007). Perbaikan genetik jagung ketan lokal perlu dilakukan untuk meningkatkan kuantitas dan kualitas hasil. Perbaikan tersebut dapat dilakukan melalui kegiatan pemuliaan tanaman dengan cara merakit varietas hibrida. Jagung ketan berpotensi dikembangkan menjadi varietas hibrida sebagai bahan baku industri khususnya produksi pati (Kopyra et al., 2012). Keunggulan varietas hibrida yaitu dapat memberikan hasil terbaik dari hasil persilangan antar galur murni. Varietas hibrida merupakan generasi pertama (F1) dari persilangan antar galur murni yang mempunyai karakter unggul. Pembentukan galur murni dilakukan dengan cara selfing paling sedikit lima generasi untuk meningkatkan homozigositas tanaman (Syukur et al., 2012). Jagung Lombok Putih dan Walamize Putih yang digunakan dalam penelitian ini termasuk jenis jagung ketan lokal asal Indonesia Timur yang merupakan generasi S1. Evaluasi terhadap generasi S1 jagung perlu dilakukan untuk mempelajari penampilan individu dan populasi di lapangan.

Penelitian ini bertujuan untuk melakukan evaluasi beberapa karakter kuantitatif, kualitatif, dan potensi sifat prolifik pada generasi S1 jagung. Varietas jagung ketan yang akan dihasilkan dalam jangka panjang yaitu varietas hibrida jagung ketan berdaya hasil tinggi, mempunyai rasa manis, serta jumlah tongkol banyak untuk menghasilkan jagung semi dalam satu tanaman.

\section{BAHAN DAN METODE}

Penelitian dilaksanakan pada bulan Februari hingga Mei 2017 di Kebun Percobaan Leuwikopo dan Departemen Agronomi dan Hortikultura IPB. Bahan genetik yang digunakan dalam penelitian ini yaitu 15 genotipe $S 1$ jagung ketan lokal (JLP1-7, JWP12-3, JWP12-1, JWP127, JWP12-5, JWP12-8, JLP1-6, JWP22- 1, JWP12-6, JWP12-2, JWP12-4, JWP22-2, JLP1-3, JLP1-5, dan JLP1-2), 1 genotipe S1 jagung manis $\mathrm{SD} 2$, dan 1 varietas pembanding URI. Bahan lain yang digunakan yaitu pupuk kandang ayam, pupuk urea, SP-36, KCl, insektisida, dan fungisida. Alat yang digunakan yaitu alat budidaya pertanian, jangka sorong, kertas sungkup, gunting, straples, label, tali plastik, kantong plastik, meteran, timbangan, dan alat tulis.

Penelitian ini menggunakan rancangan kelompok lengkap teracak faktor tunggal yaitu genotipe. Jumlah genotipe yang digunakan terdiri atas 16 genotipe uji dan 1 varietas pembanding dengan 3 ulangan sehingga terdapat 51 satuan percobaan. Setiap satuan percobaan terdiri atas 20 tanaman dan diamati 10 tanaman sebagai tanaman contoh. 
Pengolahan tanah dilakukan secara olah tanah sempurna dan dilanjutkan dengan pemberian pupuk kandang ayam. Penanaman setiap genotipe dalam satu baris dengan jarak tanam $70 \mathrm{~cm} \times 20 \mathrm{~cm}$ dengan 1 benih per lubang tanam. Benih yang ditanam diberikan insektisida berbahan aktif karbofuran dan fungisida berbahan aktif dimetomort $80 \%$. Penyulaman dilakukan pada 1 MST. Aplikasi pupuk dilakukan 2 kali yaitu pada 7 hari setelah tanam menggunakan pupuk urea $150 \mathrm{~kg} \mathrm{ha}^{-1}$, SP$36200 \mathrm{~kg} \mathrm{ha}^{-1}$, dan $\mathrm{KCl} 100 \mathrm{~kg} \mathrm{ha}^{-1}$. Aplikasi kedua menggunakan pupuk urea dengan dosis $150 \mathrm{~kg} \mathrm{ha}^{-1}$ pada umur 30 hari setelah tanam. Pemberian pupuk dengan cara dialur pada jarak \pm $8 \mathrm{~cm}$ dari lubang tanam dengan kedalaman \pm 10 $\mathrm{cm}$. Pengendalian gulma dilakukan dua kali secara manual pada umur 14-20 hari setelah tanam bersamaan dengan pembumbunan dan pada 6 minggu setelah tanam. Pengendalian organisme pengganggu tanaman berupa hama dan penyakit menggunakan insektisida berbahan aktif karbofuran dengan dosis $5 \mathrm{~kg} \mathrm{ha}^{-1}$ dan profenofos $500 \mathrm{~g} \mathrm{~L}^{-1}$ serta fungisida berbahan aktif mankozeb $80 \%$ dengan konsentrasi $3 \mathrm{~g} \mathrm{~L}^{-1}$.

Penyerbukan sendiri (selfing) dilakukan pada 5 tanaman selain tanaman contoh pada setiap genotipe. Tahapan selfing terdiri atas isolasi dan kastrasi bunga betina, isolasi bunga jantan, penyerbukan sendiri, dan pemberian label hasil selfing. Pemanenan jagung semi dilakukan terhadap tongkol selain tongkol pertama dan kedua pada 3-5 hari setelah bunga betina muncul dan belum dibuahi. Bagian tongkol sudah keluar rambut 3-5 cm dan warna kelobot hijau tua. Panen jagung muda dilakukan saat tongkol jagung sudah terisi sempurna namun daun masih hijau. Cara melakukan pemanenan yaitu dengan memotong pangkal tongkol dari batang. Pemanenan jagung ketan dilakukan pada saat tongkol jagung sudah terisi sempurna yang ditandai oleh rambut tongkol yang sudah berwarna coklat kehitaman dan mengering (18-22 hari setelah penyerbukan atau sekitar 68-72 HST).

Pengamatan dilakukan terhadap peubah kuantitatif dan kualitatif 10 tanaman contoh setiap genotipe pada setiap ulangan (Deskriptor IBPGR, 1991). Peubah kuantitatif yang diamati diantaranya yaitu daya tumbuh (\%), umur berbunga jantan (hari), umur berbunga betina (hari), ASI (Anthesis Silking Interval) (hari), jumlah buku tanaman ${ }^{-1}$ (buku), jumlah tongkol tanaman $^{-1}$ (tongkol), diameter batang $(\mathrm{mm})$, tinggi tanaman $(\mathrm{cm})$, tinggi tongkol utama $(\mathrm{cm})$, persentase tongkol layak pasar untuk jagung semi (\%), persentase tongkol afkir untuk jagung semi
(\%), panjang tongkol jagung $(\mathrm{cm})$, diameter tongkol (mm), jumlah baris biji (baris), bobot tongkol berkelobot $(\mathrm{g})$, dan bobot tongkol tanpa kelobot (g). Peubah kualitatif yang diamati diantaranya yaitu warna batang, warna silk, susunan baris biji, dan warna biji.

Data yang diperoleh dianalisis menggunakan uji F. Jika perlakuan berpengaruh nyata dilakukan uji lanjut DMRT pada taraf $\alpha$ 5\%. Analisis data menggunakan software SAS versi 9.1.3 dan minitab. Hubungan antar peubah dianalisis menggunakan analisis korelasi pearson untuk mengetahui derajat keeratan antar peubah. Nilai heritabilitas dianalisis menggunakan pendugaan komponen ragam hasil analisis ragam.

\section{HASIL DAN PEMBAHASAN}

\section{Kondisi Umum Penelitian}

Curah hujan selama penelitian berkisar antara 284-526 mm bulan ${ }^{-1}$. Curah hujan dengan kriteria sangat tinggi terjadi pada bulan Februari yaitu $526 \mathrm{~mm}$ bulan $^{-1}$ dengan kelembapan $88 \%$. Suhu paling tinggi pada bulan Mei yaitu $26,4{ }^{\circ} \mathrm{C}$ (BMKG, 2017).

Daya tumbuh rata-rata dari seluruh genotipe yang ditanam yaitu $78,59 \%$. Daya tumbuh tersebut diduga dipengaruhi oleh kualitas benih. Menurut Umar (2012) kualitas benih dipengaruhi oleh unsur benih itu sendiri dan unsur lingkungan terutama ruang penyimpanan. Penyulaman dilakukan pada baris percobaan yang kekurangan jumlah individu tanaman. Penyakit utama yang menyerang tanaman jagung selama penelitian yaitu penyakit bulai (Peronosclerospora maydis) dan busuk batang. Penyakit bulai menyerang pada masa vegetatif yaitu sekitar 37 HST. Infeksi bulai terjadi pada genotipe JWP12-5, JLP1-3, dan JLP1-2. Pengendalian penyakit bulai dengan cara langsung yaitu tanaman yang terinfeksi bulai dibersihkan dari lahan dengan cara dicabut dan dibuang menjauhi lahan. Busuk batang menginfeksi bagian pangkal batang, mengeluarkan bau tidak sedap, berair, daun layu, dan tanaman rebah. Pengendalian dilakukan secara langsung dengan mencabut tanaman yang sakit dan dengan aplikasi fungisida berbahan aktif mankozeb $80 \%$ secara periodik.

Hama utama yang menyerang tanaman jagung selama penelitian yaitu ulat, penggerek batang, dan penggerek tongkol. Ulat menyerang pada masa vegetatif mengakibatkan daun rusak. Serangan penggerek batang yang berat mengakibatkan batang menjadi patah dan aliran hara terhambat. Perkembangan tongkol yang 
terserang penggerek menjadi tidak sempurna. Pengendalian hama utama tersebut dilakukan secara periodik dengan aplikasi insektisida berbahan aktif profenofos $500 \mathrm{~g} \mathrm{~L}^{-1}$.

\section{Keragaan Karakter Kuantitatif}

Hasil rekapitulasi sidik ragam keragaan 17 genotipe jagung (Tabel 1) menunjukkan bahwa genotipe jagung berpengaruh nyata terhadap umur berbunga jantan, umur berbunga betina, anthesis silking interval diameter batang, tinggi tanaman, tinggi tongkol utama, panjang tongkol, diameter tongkol, dan bobot tongkol tanpa kelobot. Setiap genotipe memiliki karakter yang berbeda pada peubah tersebut. Genotipe tidak berpengaruh terhadap karakter pertumbuhan dan komponen hasil lainnya.

Tabel 1. Rekapitulasi sidik ragam keragaam 17 genotipe jagung generasi S1

\begin{tabular}{lcc}
\hline Karakter & F hitung & KK (\%) \\
\hline Umur berbunga jantan (hari) & $5,70 * *$ & 3,45 \\
Umur berbunga betina (hari) & $2,81 * *$ & 4,63 \\
Anthesis silking interval (hari) & $3,43 * *$ & 30,45 \\
Jumlah buku tanaman-1 (buku) & $1,40 \mathrm{tn}$ & 6,81 \\
Jumlah tongkol tanaman-1 (tongkol) & $1,71 \mathrm{tn}$ & $12,25^{\mathrm{a}}$ \\
Diameter batang (mm) & $3,31 * *$ & 12,09 \\
Tinggi tanaman (cm) & $3,83 * *$ & 8,93 \\
Persentase tongkol layak pasar (\%) & $3,04 \mathrm{tn}$ & $13,32^{\mathrm{a}}$ \\
Persentase tongkol afkir (\%) & $2,06 \mathrm{tn}$ & 29,18 \\
Tinggi tongkol utama (cm) & $3,11 * *$ & 14,98 \\
Panen Muda & & \\
Panjang tongkol (cm) & $2,17 *$ & 28,43 \\
Diameter tongkol (mm) & $2,10 \mathrm{tn}$ & 21,37 \\
Jumlah baris biji (baris) & $0,93 \mathrm{tn}$ & 21,94 \\
Bobot tongkol berkelobot (g) & $1,28 \mathrm{tn}$ & $18,64^{\mathrm{a}}$ \\
Bobot tongkol tanpa kelobot (g) & $1,31 \mathrm{tn}$ & $37,86^{\mathrm{a}}$ \\
Panen Tua & & \\
Panjang tongkol (cm) & $1,40 \mathrm{tn}$ & 26,56 \\
Diameter tongkol (mm) & $17,90 * *$ & 7,13 \\
Jumlah baris biji (baris) & $5,28 \mathrm{tn}$ & 14,22 \\
Bobot tongkol berkelobot (g) & $3,37 \mathrm{tn}$ & 27,62 \\
Bobot tongkol tanpa kelobot (g) & $69,29 * *$ & 10,76 \\
\hline Keterngan :
\end{tabular}

Keterangan : $* *=$ berpengaruh nyata pada $\alpha 1 \%$; $=$ berpengaruh nyata pada taraf $\alpha 5 \%$; th $=$ tidak berpengaruh nyata pada taraf $\alpha 5 \% ; \mathrm{KK}=$ Koefisien Keragaman; $^{\text {a }}=$ data hasil transformasi $(\sqrt{ }$ $\mathrm{x}+0,5)$

Hasil analisis ragam (Tabel 1) menunjukkan bahwa terdapat nilai koefisien keragaman (KK) yang berbeda pada setiap karakter yang diamati. Nilai koefisien keragaman (KK) berkisar antara 3,45-37,86\%. Karakter bobot tongkol tanpa kelobot panen muda mempunyai nilai koefisien keragaman (KK) yang paling tinggi yaitu $37,86 \%$. Karakter umur berbunga jantan mempunyai nilai koefisien keragaman yang paling rendah yaitu $3,45 \%$. Nilai koefisien keragaman merupakan tolak ukur ketepatan dalam percobaan yang berhubungan dengan galat percobaan. Menurut Gomez dan Gomez, 1995 semakin rendah nilai koefisien keragaman (KK) maka semakin tinggi keakuratan dalam penelitian.

Rataan jumlah buku $\operatorname{tanaman}^{-1}$ setiap genotipe berkisar antara 9-10 buku. Hal tersebut sesuai dengan hasil penelitian Sari (2015) yang menyatakan bahwa jumlah buku tanaman ${ }^{-1}$ genotipe lokal JWP22 dan JLP1 lebih rendah dari 13,40 buku. Hasil penelitian menunjukkan bahwa genotipe tidak berpengaruh nyata terhadap jumlah buku tetapi berpengaruh nyata terhadap tinggi tanaman. Hal tersebut berarti genotipe uji memiliki ukuran ruas yang panjang. Rata-rata jumlah tongkol $\operatorname{tanaman}^{-1}$ yaitu 1-3 tongkol. Menurut Yudiwanti et al. (2006) tanaman jagung dengan jumlah tongkol dua atau lebih termasuk tipe prolifik. Karakter prolifik dipengaruhi oleh faktor genetik dan faktor lingkungan. Tongkol layak pasar dan tongkol afkir merupakan kriteria untuk panen jagung semi (baby corn). Rataan persentase tongkol layak pasar dan tongkol afkir berkisar antara 6,50-10,05\% dan 11,11$100 \%$. Rataan diameter tongkol, jumlah baris biji, bobot tongkol berkelobot, dan bobot tongkol tanpa kelobot panen muda masing-masing 
berkisar antara 11,16-30,10 $\mathrm{mm}, 7,00-13,00$ baris, 6,24-10,24 g, dan 2,61-7,79 g.

Genotipe berpengaruh nyata terhadap diameter batang. Hal tersebut menunjukkan bahwa diameter batang antar genotipe berbeda. Diameter batang merupakan bagian penting untuk menopang tanaman dan mendukung pertumbuhan akar udara tanaman jagung. Rataan diameter batang berkisar antara 13,43-21,00 mm (Tabel 2). Genotipe SD2 memiliki diameter batang terbesar yaitu $21,00 \mathrm{~mm}$ tidak berbeda nyata dengan genotipe JWP12-5 dan JWP12-8. Varietas URI memiliki diameter batang terkecil yaitu 13,43 mm. Genotipe JWP12-5, SD2, JWP12-8, JWP126, JWP12-2, JWP12-4, JWP22-2, JLP1-5, dan JLP1-2 memiliki diameter batang nyata lebih besar dibandingkan dengan varietas URI. Terdapat tujuh genotipe dengan diameter batang yang relatif sama dengan varietas URI.
Genotipe berpengaruh nyata terhadap tinggi tanaman. Rataan tinggi tanaman berkisar antara 105,71-183,86 cm (Tabel 2). Genotipe JWP12-4 memiliki tinggi tanaman tertinggi yaitu $183,86 \mathrm{~cm}$ sedangkan varietas pembanding URI memiliki tinggi tanaman terpendek yaitu $105,71 \mathrm{~cm}$. Hasil penelitian tersebut sesuai dengan yang telah dilaporkan oleh Sirajuddin (2014) yang menyatakan bahwa tinggi tanaman terendah terdapat pada genotipe pembanding pulut URI yaitu $115,67 \mathrm{~cm}$. Seluruh genotipe uji memiliki tinggi tanaman yang berbeda nyata lebih tinggi dari varietas URI. Tinggi tanaman merupakan komponen penting dalam kegiatan pemuliaan tanaman. Secara umum, program pemuliaan jagung diharapkan mampu mendapatkan tanaman dengan ukuran rendah dan hasil panen yang lebih banyak (Edmeades dan Lafitte, 1993).

Tabel 2. Rataan karakter-karakter pertumbuhan 17 genotipe jagung generasi S1

\begin{tabular}{lcccccc}
\hline Genotipe & $\begin{array}{c}\text { Diameter } \\
\text { Batang } \\
(\mathrm{mm})\end{array}$ & $\begin{array}{c}\text { Tinggi } \\
\text { Tanaman } \\
(\mathrm{cm})\end{array}$ & $\begin{array}{c}\text { Tinggi } \\
\text { Tongkol } \\
\text { Utama }(\mathrm{cm})\end{array}$ & $\begin{array}{c}\text { Umur } \\
\text { Berbunga } \\
\text { Jantan (hari) }\end{array}$ & $\begin{array}{c}\text { Umur } \\
\text { Berbunga } \\
\text { Betina (hari) }\end{array}$ & $\begin{array}{c}\text { Anthesis is } \\
\text { Silking } \\
\text { Interval } \text { (hari) }\end{array}$ \\
\hline JLP1-7 & $16,92 \mathrm{abc}$ & $154,34 \mathrm{~b}$ & $63,96 \mathrm{bcd}$ & $54,00 \mathrm{~b}$ & $59,66 \mathrm{ab}$ & $5,66 \mathrm{a}$ \\
JWP12-3 & $16,94 \mathrm{abc}$ & $168,46 \mathrm{ab}$ & $79,26 \mathrm{abc}$ & $51,33 \mathrm{~b}$ & $53,66 \mathrm{~cd}$ & $2,33 \mathrm{bcd}$ \\
JWP12-1 & $17,32 \mathrm{abc}$ & $168,61 \mathrm{ab}$ & $84,16 \mathrm{abc}$ & $52,33 \mathrm{~b}$ & $56,66 \mathrm{abc}$ & $4,33 \mathrm{ab}$ \\
JWP12-7 & $15,94 \mathrm{bc}$ & $161,00 \mathrm{ab}$ & $81,08 \mathrm{abc}$ & $52,66 \mathrm{~b}$ & $57,66 \mathrm{abc}$ & $5,00 \mathrm{a}$ \\
JWP12-5 & $20,11 \mathrm{a}$ & $158,85 \mathrm{ab}$ & $88,23 \mathrm{a}$ & $53,33 \mathrm{~b}$ & $57,00 \mathrm{abc}$ & $4,00 \mathrm{ab}$ \\
SD2 & $21,00 \mathrm{a}$ & $148,73 \mathrm{~b}$ & $68,66 \mathrm{abc}$ & $59,33 \mathrm{a}$ & $60,33 \mathrm{a}$ & $1,00 \mathrm{~d}$ \\
JWP12-8 & $20,71 \mathrm{a}$ & $155,89 \mathrm{~b}$ & $77,46 \mathrm{abc}$ & $54,00 \mathrm{~b}$ & $59,33 \mathrm{ab}$ & $5,33 \mathrm{a}$ \\
JLP1-6 & $13,44 \mathrm{c}$ & $153,86 \mathrm{~b}$ & $74,41 \mathrm{abc}$ & $52,66 \mathrm{~b}$ & $57,33 \mathrm{abc}$ & $4,66 \mathrm{ab}$ \\
JWP22-1 & $15,64 \mathrm{bc}$ & $158,41 \mathrm{ab}$ & $74,14 \mathrm{abc}$ & $51,66 \mathrm{~b}$ & $55,00 \mathrm{bc}$ & $3,33 \mathrm{abc}$ \\
JWP12-6 & $18,44 \mathrm{ab}$ & $145,82 \mathrm{~b}$ & $72,26 \mathrm{abc}$ & $54,33 \mathrm{~b}$ & $59,00 \mathrm{ab}$ & $4,66 \mathrm{ab}$ \\
JWP12-2 & $18,05 \mathrm{ab}$ & $158,03 \mathrm{ab}$ & $69,34 \mathrm{abc}$ & $52,00 \mathrm{~b}$ & $56,00 \mathrm{abc}$ & $4,00 \mathrm{ab}$ \\
JWP12-4 & $18,51 \mathrm{ab}$ & $183,86 \mathrm{a}$ & $85,73 \mathrm{ab}$ & $52,33 \mathrm{~b}$ & $57,00 \mathrm{abc}$ & $4,66 \mathrm{ab}$ \\
JWP22-2 & $18,12 \mathrm{ab}$ & $147,89 \mathrm{~b}$ & $62,22 \mathrm{~cd}$ & $46,33 \mathrm{c}$ & $49,66 \mathrm{~d}$ & $3,33 \mathrm{abc}$ \\
JLP1-3 & $15,35 \mathrm{bc}$ & $156,45 \mathrm{~b}$ & $90,50 \mathrm{a}$ & $51,00 \mathrm{~b}$ & $55,00 \mathrm{bc}$ & $4,00 \mathrm{ab}$ \\
JLP1-5 & $18,20 \mathrm{ab}$ & $155,04 \mathrm{~b}$ & $91,09 \mathrm{a}$ & $51,66 \mathrm{~b}$ & $55,66 \mathrm{abc}$ & $4,00 \mathrm{ab}$ \\
JLP1-2 & $18,92 \mathrm{ab}$ & $163,33 \mathrm{ab}$ & $84,00 \mathrm{abc}$ & $52,33 \mathrm{~b}$ & $57,33 \mathrm{abc}$ & $5,00 \mathrm{a}$ \\
\hline URI & $13,43 \mathrm{c}$ & $105,71 \mathrm{c}$ & $46,86 \mathrm{~d}$ & $54,00 \mathrm{~b}$ & $55,66 \mathrm{abc}$ & $1,66 \mathrm{~cd}$ \\
\hline K & $\mathrm{y}$ &
\end{tabular}

Keterangan: Angka yang diikuti huruf yang sama pada kolom yang sama tidak berbeda nyata berdasarkan uji DMRT pada taraf $\alpha 5 \%$

Genotipe berpengaruh nyata terhadap tinggi tongkol utama. Rataan tinggi tongkol utama berkisar antara 46,86-91,09 $\mathrm{cm}$ (Tabel 2). Genotipe JLP1-5 memiliki tinggi tongkol utama tertinggi yaitu 91,09 sedangkan varietas pembanding URI memiliki tinggi tongkol utama terendah yaitu 46,86 cm. JLP1-7 dan JWP22-2 memiliki tinggi tongkol utama yang tidak berbeda nyata dengan varietas URI. Terdapat 14 genotipe uji yang memiliki tinggi tongkol utama yang berbeda nyata lebih tinggi dibandingkan varietas URI.
Jagung memiliki bunga jantan dan bunga betina yang terpisah dalam satu tanaman sehingga umur berbunga tanaman tersebut dibedakan menjadi umur berbunga jantan dan umur berbunga betina. Genotipe berpengaruh nyata terhadap umur berbunga jantan. Rataan umur berbunga jantan berkisar antara 46-59 hari (Tabel 2). Genotipe JWP22-2 memiliki umur berbunga jantan paling cepat yaitu 46 hari. Menurut Sari (2015) genotipe lokal JWP22 memiliki umur berbunga jantan yang genjah yaitu 48 hari. Genotipe SD2 memiliki umur berbunga jantan paling lambat yaitu 59 hari. Sebanyak 14 
genotipe uji memiliki umur berbunga jantan yang tidak berbeda nyata dengan genotipe pembanding URI. Genotipe uji jagung ketan mempunyai karakter tipe malai yang berbeda dengan jagung manis. Tipe malai tersebut mempengaruhi jumlah polen jagung ketan lebih sedikit dibandingkan dengan jagung manis.

Genotipe berpengaruh nyata terhadap umur berbunga betina. Rataan umur berbunga betina berkisar antara 49-60 hari (Tabel 2). Genotipe JWP22-2 memiliki umur berbunga betina paling cepat yaitu 49 hari sedangkan genotipe SD2 memiliki umur berbunga betina paling lambat yaitu 60 hari. Genotipe JWP12-3 mempunyai umur berbunga betina yang relatif sama dengan genotipe JWP22-2. Sebanyak 15 genotipe uji memiliki umur berbunga betina yang relatif sama dengan varietas URI.

Anthesis silking interval (ASI) merupakan selisih antara muncul bunga jantan dengan bunga betina. Genotipe berpengaruh terhadap ASI. Rataan ASI berkisar antara 1-5 hari (Tabel 2).
Genotipe SD2 merupakan genotipe yang memiliki ASI yang paling cepat yaitu 1 hari. Genotipe JLP1-7 memiliki ASI yang paling lama yaitu 5 hari. Genotipe JWP12-3, SD2, JWP22-1, dan JWP22-2 memiliki ASI yang tidak berbeda nyata dengan varietas URI. Sebanyak 12 genotipe uji memiliki anthesis silking interval berbeda nyata lebih lama dibandingkan varietas URI.

ASI yang lebih panjang memiliki kemampuan penyerbukan yang semakin rendah. Genotipe dengan karakter ASI yang lebih singkat diperlukan untuk meningkatkan kemampuan penyerbukan yang akan mempengaruhi komponen hasil. Bunga betina diharapkan akan terserbuki maksimal jika selang antara umur berbunga jantan dan bunga betina tidak terlalu lama. Menurut Adriani et al. (2015) nilai ASI yang kecil memberikan hasil penyerbukan yang sempurna dan akan berpengaruh terhadap pengisian biji. Jumlah biji yang terbentuk tergantung oleh jumlah rambut yang diserbuki oleh serbuk sari.

Tabel 3. Rataan karakter-karakter komponen hasil 17 genotipe jagung generasi S1

\begin{tabular}{lcccccc}
\hline Karakter & $\begin{array}{c}\text { Bobot Tongkol } \\
\text { Berkelobot } \\
\text { Panen Tua }(\mathrm{g})\end{array}$ & $\begin{array}{c}\text { Bobot } \\
\text { Tongkol } \\
\text { Tanpa } \\
\text { Kelobot } \\
\text { Panen Tua }(\mathrm{g})\end{array}$ & $\begin{array}{c}\text { Diameter } \\
\text { Tongkol } \\
\text { Panen Tua } \\
(\mathrm{mm})\end{array}$ & $\begin{array}{c}\text { Panjang } \\
\text { Tongkol } \\
\text { Panen Tua } \\
(\mathrm{cm})\end{array}$ & $\begin{array}{c}\text { Jumlah } \\
\text { Baris Biji } \\
\text { Panen Tua } \\
\text { (baris })\end{array}$ & $\begin{array}{c}\text { Panjang } \\
\text { Tongkol } \\
\text { Panen Muda } \\
(\mathrm{cm})\end{array}$ \\
\hline JLP1-7 & - & - & - & - & - & $8,70 \mathrm{bc}$ \\
JWP12-3 & $41,18 \mathrm{bc}$ & $19,72 \mathrm{ef}$ & $23,49 \mathrm{~cd}$ & $7,66 \mathrm{abc}$ & $8,00 \mathrm{~b}$ & $9,00 \mathrm{bc}$ \\
JWP12-1 & - & - & - & - & - & $7,50 \mathrm{bc}$ \\
JWP12-7 & - & - & - & - & - & $5,00 \mathrm{c}$ \\
JWP12-5 & $21,00 \mathrm{c}$ & $9,90 \mathrm{fg}$ & $16,31 \mathrm{fg}$ & $6,75 \mathrm{bc}$ & $8,50 \mathrm{~b}$ & $10,25 \mathrm{abc}$ \\
SD2 & $100,50 \mathrm{a}$ & $93,90 \mathrm{a}$ & $39,41 \mathrm{a}$ & $15,75 \mathrm{bc}$ & $18,00 \mathrm{a}$ & $13,25 \mathrm{ab}$ \\
JWP12-8 & $21,35 \mathrm{c}$ & $8,15 \mathrm{fg}$ & $20,00 \mathrm{def}$ & $9,75 \mathrm{abc}$ & $6,00 \mathrm{~b}$ & $8,72 \mathrm{bc}$ \\
JLP1-6 & $48,40 \mathrm{abc}$ & $36,40 \mathrm{sd}$ & $26,21 \mathrm{c}$ & $13,00 \mathrm{abc}$ & $9,00 \mathrm{~b}$ & $10,42 \mathrm{abc}$ \\
JWP22-1 & $79,60 \mathrm{ab}$ & $43,70 \mathrm{bc}$ & $23,60 \mathrm{~cd}$ & $16,50 \mathrm{a}$ & $10,00 \mathrm{~b}$ & $7,37 \mathrm{bc}$ \\
JWP12-6 & $36,25 \mathrm{bc}$ & $23,55 \mathrm{de}$ & $24,11 \mathrm{~cd}$ & $7,15 \mathrm{bc}$ & $9,00 \mathrm{~b}$ & $7,94 \mathrm{bc}$ \\
JWP12-2 & - & - & - & - & - & $10,58 \mathrm{abc}$ \\
JWP12-4 & $21,53 \mathrm{c}$ & $7,46 \mathrm{fg}$ & $18,77 \mathrm{efg}$ & $6,16 \mathrm{c}$ & $7,50 \mathrm{~b}$ & $7,25 \mathrm{c}$ \\
JWP22-2 & - & - & - & - & - & $8,00 \mathrm{bc}$ \\
JLP1-3 & $28,70 \mathrm{bc}$ & $6,00 \mathrm{~g}$ & $15,00 \mathrm{~g}$ & $7,00 \mathrm{ab}$ & - & $5,00 \mathrm{c}$ \\
JLP1-5 & $63,65 \mathrm{abc}$ & $33,90 \mathrm{~cd}$ & $22,49 \mathrm{cde}$ & $10,12 \mathrm{abc}$ & $10,00 \mathrm{~b}$ & $9,33 \mathrm{bc}$ \\
JLP1-2 & $40,70 \mathrm{bc}$ & $5,40 \mathrm{~g}$ & $23,71 \mathrm{~cd}$ & $13,50 \mathrm{abc}$ & - & $15,25 \mathrm{a}$ \\
\hline URI & $69,68 \mathrm{abc}$ & $52,32 \mathrm{~b}$ & $31,76 \mathrm{~b}$ & $10,91 \mathrm{abc}$ & $10,47 \mathrm{~b}$ & $10,12 \mathrm{abc}$ \\
\hline Keterangan: & Angka yang diikuti huruf yang sama pada kolom yang sama tidak berbeda nyata berdasarkan uji
\end{tabular}

Rataan bobot tongkol berkelobot, panjang tongkol, jumlah baris biji panen tua masingmasing berkisar antara 21,00-100,50 gram, 6,16$16,50 \mathrm{~cm}$, dan 6,00-18,00 baris (Tabel 3). Genotipe berpengaruh nyata terhadap diameter tongkol panen tua. Rataan diameter tongkol panen tua berkisar antara 15,00-39,41 mm (Tabel 3). Genotipe SD2 memiliki diameter tongkol paling besar yaitu 39,41 mm. Genotipe JLP1-3 memiliki diameter tongkol paling kecil yaitu $15,00 \mathrm{~mm}$. Sebanyak 10 genotipe memiliki diameter tongkol panen tua yang berbeda nyata lebih kecil dari varietas URI.

Genotipe berpengaruh nyata terhadap bobot tongkol tanpa kelobot panen tua. Rataan bobot tongkol tanpa kelobot berkisar antara 5,40- 
93,90 gram. Genotipe SD2 memiliki bobot tongkol tanpa kelobot paling besar yaitu 93,90 gram. Genotipe JLP1-2 memiliki bobot tongkol tanpa kelobot paling kecil dan tidak berbeda nyata dengan genotipe JWP12-5, JWP12-8, JWP12-4, dan JLP1-3. Sebanyak 10 genotipe berbeda nyata lebih kecil dari varietas URI.

Genotipe berpengaruh nyata terhadap panjang tongkol panen muda. Panen muda merupakan panen jagung untuk dikonsumsi dalam bentuk jagung segar. Kriteria panen muda yaitu biji sudah terisi penuh dan daun masih hijau. Rataan panjang tongkol berkisar antara 5$15,25 \mathrm{~cm}$ (Tabel 3). Genotipe JLP1-2 memiliki panjang tongkol terpanjang yaitu $15,25 \mathrm{~cm}$. Genotipe JWP12-7 dan JLP1-3 memiliki panjang tongkol terpendek yaitu $5 \mathrm{~cm}$. Genotipe JWP12-5, JLP1-6, dan JWP12-2 memiliki panjang tongkol yang tidak berbeda nyata dengan varietas URI.

\section{Heritabilitas}

Karakter kuantitatif dikendalikan oleh banyak gen dan dipengaruhi oleh faktor lingkungan. Pendugaan nilai heritabilitas digunakan untuk mengetahui peranan faktorfaktor genetik dari fenotipe yang tampak (Syukur et al., 2012). Heritabilitas arti luas $\left(\mathrm{h}^{2}\right.$ bs $)$ merupakan perbandingan antara ragam genetik total dan ragam fenotipe. Nilai heritabilitas arti luas $\left(\mathrm{h}_{\mathrm{bs}}^{2}\right)$ untuk karakter yang dievaluasi berkisar antara 0,91-98,42\%. Pendugaan nilai heritabilitas menurut MendezNatera et al (2012) dikelompokkan menjadi tiga yaitu heritabilitas tinggi $(H \geq 0,5)$, heritabilitas sedang $(0,2<\mathrm{H}<0,5)$, dan heritabilitas rendah $(\mathrm{H} \leq 0,2)$.

Tabel 4. Nilai duga komponen ragam dan heritabilitas arti luas tiap peubah pada 16 genotipe S1 dan varietas pembanding jagung

\begin{tabular}{lrrrrl}
\hline Karakter & \multicolumn{1}{c}{$\mathrm{Vg}$} & \multicolumn{1}{c}{$\mathrm{Ve}$} & \multicolumn{1}{c}{$\mathrm{Vp}^{2}$} & $\mathrm{~h}_{\text {bs }}(\%)$ & Kriteria \\
\hline Umur berbunga jantan & 5,15 & 1,10 & 6,25 & 82,38 & Tinggi \\
Umur berbunga betina & 4,35 & 2,28 & 6,63 & 65,52 & Tinggi \\
Anthesis silking interval & 1,00 & 0,47 & 1,48 & 67,92 & Tinggi \\
Diameter batang & 2,89 & 1,48 & 4,38 & 66,02 & Tinggi \\
Tinggi tanaman & 160,32 & 64,41 & 224,73 & 71,34 & Tinggi \\
Panjang tongkol panen muda & 2,22 & 2,25 & 4,47 & 49,63 & Sedang \\
Diameter tongkol panen tua & 15,56 & 1,00 & 16,56 & 93,94 & Tinggi \\
Bobot tongkol tanpa kelobot panen tua & 227,36 & 3,64 & 231,00 & 98,42 & Tinggi \\
\hline
\end{tabular}

Keterangan : $\mathrm{Vg}=$ Ragam genotipe, $\mathrm{Ve}=$ ragam lingkungan, $\mathrm{Vp}=$ ragam fenotipe, $\mathrm{h}^{2} \mathrm{bs}=$ heritabilitas dalam arti luas, heritabilitas tinggi $=\left(h^{2} b s>0.5\right)$, heritabilitas sedang $=\left(0,2<h^{2} b s>0,5\right)$, heritabilitas rendah $=\left(\mathrm{h}^{2} \mathrm{bs}<0,2\right)$

Hasil evaluasi terhadap karakter yang diamati terdapat 7 karakter yang memiliki nilai heritabilitas arti luas $\left(\mathrm{h}_{\mathrm{bs}}^{2}\right)$ yang tinggi (Tabel 8). Karakter-karakter tersebut yaitu umur berbunga jantan, umur berbunga betina, anthesis silking interval, diameter batang, tinggi tanaman, diameter tongkol panen tua, dan bobot tongkol tanpa kelobot panen tua. Nilai heritabilitas dari karakter-karakter tersebut berkisar antara 65,52-98,42\%. Nilai heritabilitas yang tinggi berarti faktor genetik lebih mempengaruhi daripada faktor lingkungan terhadap fenotipe dan lebih besar peluang untuk karakter tersebut diwariskan kepada keturunannya. Seleksi pada karakter dengan nilai heritabilitas tinggi dapat dilakukan pada generasi awal (Wicaksana, 2001). Menurut Moedjiono dan Mejaya (1994) keefektifan seleksi akan semakin efisien pada karakter dengan nilai duga heritabilitas yang tinggi.

Karakter panjang tongkol panen muda memiliki nilai heritabilitas arti luas yang sedang yaitu 49,63\% (Tabel 4). Heritabilitas yang sedang berarti faktor genetik dan faktor lingkungan sama-sama mempengaruhi karakter tersebut.

\section{Keragaan Karakter Kualitatif}

Pengamatan karakter kualitatif dilakukan secara visual. Karakter kualitatif yang diamati antara lain warna batang, susunan baris biji, warna biji, tipe biji, dan wana silk. Genotipe JLP1-7, SD2, JLP1-6, JLP1-2, dan URI memiliki warna batang hijau (Tabel 6). Hasil penelitian menunjukkan bahwa genotipe JWP123, JWP12-8, JWP12-6, dan JWP12-4 memiliki warna batang kemerahan. Delapan genotipe memiliki warna batang yang masih beragam. Keadaan tersebut menunjukkan bahwa genetik pada generasi S1 jagung masih heterogen. Menurut Syukur et al. (2012) karakter kualitatif dikendalikan oleh gen sederhana dan sedikit dipengaruhi oleh lingkungan. 
Tabel 5. Keragaan Karakter kualitatif 17 genotipe jagung generasi S1

\begin{tabular}{lcccc}
\hline Genotipe & Warna Batang & Susunan Baris Biji & Warna Biji & Warna Silk \\
\hline JLP1-7 & Hijau & Regular & Putih & Kuning \\
JWP12-3 & Kemerahan & Irregular & Putih & Kuning \\
JWP12-1 & Ungu,kemerahan & Regular & Puth & Merah keputih-putihan,kuning \\
JWP12-7 & Hijau,merah,kemerahan & Regular & Putih & Merah keputih-putihan,kuning \\
JWP12-5 & Merah,kemerahan & Regular & Putih & Merah keputih-putihan,kuning \\
SD2 & Hijau & Regular & Kuning & Kuning \\
JWP12-8 & Kemerahan & Irregular & Putih & Merah keputih-putihan,kuning \\
JLP1-6 & Hijau & Regular & Puth & Merah keputih-putihan,kuning \\
JWP22-1 & Hijau,kemerahan & Regular & Putih & Kuning \\
JWP12-6 & Kemerahan & Irregular & Puth & Kuning \\
JWP12-2 & Coklat,kemerahan & Regular & Puth & Merah keputh-putihan,kuning \\
JWP12-4 & Kemerahan & Regular & Putih & Merah keputih-putihan,kuning \\
JWP22-2 & Hijau,ungu,kemerahan & Regular & Putih & Kuning \\
JLP1-3 & Hijau,merah,kemerahan & Regular & Puth & Merah keputih-putihan,kuning,merah \\
JLP1-5 & Coklat,kemerahan & Regular & Putih & Merah \\
JLP1-2 & Hijau & Straight & Putih & Kuning \\
URI & Hijau & Regular & Putih & Kuning \\
\hline
\end{tabular}

Karakter pengamatan pada hasil penelitian menunjukkan bahwa susunan baris biji pada masing- masing genotipe didominasi oleh tipe regular. Genotipe JWP12-3, JWP12-8, dan JWP12-6 memiliki susunan baris biji tipe irregular sedangkan genotipe JLP1-2 memiliki susunan baris biji straight.

Karakter pengamatan warna biji pada hasil penelitian menunjukkan terdapat keseragaman warna biji pada semua genotipe jagung ketan, yaitu semua genotipe jagung ketan berwarna putih dengan tipe biji jagung ketan. Genotipe SD2 memiliki warna biji kuning dan tipe biji jagung manis.

Karakter kuantitatif warna silk pada hasil penelitian menunjukkan masih terdapat keragaman yang terdiri atas warna kuning, merah keputih-putihan, dan merah. Genotipe JLP1-7, JW12-3, SD2, JWP22-1， JWP12-6, JWP22-2, JLP1-2, dan URI memiliki warna silk kuning. Genotipe JLP1-5 memiliki warna silk yang berbeda yaitu merah. Delapan genotipe uji memiliki warna silk lebih dari satu warna.

\section{Korelasi antar Karakter Kuantitatif}

Analisis korelasi digunakan untuk mengetahui keeratan hubungan antar dua karakter atau lebih. Hasil analisis korelasi antar karakterkarakter yang diamati disajikan pada (Tabel 6). Nilai koefisien korelasi berkisar antara -1 dan 1. Menurut Gomez dan Gomez (1995) nilai koefisien korelasi -1 atau 1 menunjukkan pola hubungan yang semakin erat sedangkan nilai koefisien korelasi mendekati nol berarti pola hubungan antar karakter semakin tidak erat.
Hasil analisis korelasi dalam penelitian ini (Tabel 6) menunjukkan bahwa terdapat korelasi nyata dan positif antara umur berbunga jantan dengan umur berbunga betina dengan nilai koefisien korelasi sebesar 0,89. Hal tersebut sesuai dengan hasil penelitian Maryamah (2016) menunjukkan bahwa terdapat korelasi nyata dan positif antara umur anthesis dengan umur silking sebesar 0,98 yang artinya semakin genjah umur berbunga jantan maka semakin genjah umur berbunga betina.

Diameter tongkol, jumlah baris biji, dan bobot tongkol tanpa kelobot berkorelasi nyata dan positif terhadap umur berbunga betina dengan nilai koefisien korelasi masing-masing sebesar 0,64, 0,76, dan 0,66. Hal tersebut berkaitan dengan periode ASI. Komponen hasil berupa diameter tongkol, jumlah baris biji, dan bobot tongkol berkelobot berkorelasi nyata dan negatif terhadap anthesis silking interval dengan masing- masing nilai koefisien korelasi 0,71, -0,72, dan-0,71. Anthesis silking interval yang terlalu lama akan menurunkan beberapa komponen hasil. Hal itu terjadi akibat penyerbukan yang kurang sempurna pada tanaman jagung.

Jumlah baris biji, bobot tongkol berkelobot, dan bobot tongkol tanpa kelobot berkorelasi nyata dan positif dengan diameter tongkol dengan masing-masing nilai koefisien korelasi $0,60,0,85$, dan 0,68. Semakin banyak jumlah baris biji, semakin berat bobot tongkol berkelobot dan berat bobot tongkol tanpa kelobot maka diameter tongkol semakin besar. Karakter-karakter tersebut sangat penting sebagai pendukung komponen hasil. 
Tinggi tongkol utama berkorelasi nyata dan positif dengan tongkol layak pasar dengan nilai koefisien korelasi sebesar 0,68. Semakin tinggi tongkol utama maka semakin tinggi peluang tanaman tersebut memiliki beberapa tongkol yang dapat dijadikan sebagai jagung semi. Diameter tongkol dan bobot tongkol berkelobot berkorelasi nyata dan positif dengan panjang tongkol dengan nilai koefisien korelasi masingmasing 0,68 dan 0,79. Tongkol dengan ukuran diameter yang lebih besar dan bobot tongkol berkelobot yang semakin berat akan memiliki ukuran tongkol yang lebih panjang.

Bobot tongkol berkelobot dan bobot tongkol tanpa kelobot berkorelasi nyata dan positif dengan jumlah baris biji dengan nilai koefisien korelasi sebesar 0,83 dan 0,73 . Semakin berat bobot tongkol berkelobot dan bobot tongkol tanpa kelobot maka akan semakin banyak jumlah baris biji tongkol ${ }^{-1}$. Bobot tongkol tanpa kelobot berkorelasi nyata dan positif dengan bobot tongkol berkelobot dengan nilai koefisien korelasi sebesar 0,63.

Panjang tongkol berkorelasi nyata dan negatif dengan tinggi tongkol utama dengan nilai koefisien korelasi sebesar -0,56. Bobot tongkol tanpa kelobot berkorelasi nyata dan negatif dengan tinggi tanaman dengan nilai koefisien korelasi sebesar $-0,59$. Hal itu berbeda dengan yang dikemukakan oleh Zsubori et al. (2002) bahwa tinggi tanaman dan tinggi posisi tongkol utama berkorelasi nyata dan positif dengan komponen hasil. Menurut Dewanti et al. (2015) analisis korelasi dapat digunakan untuk mengetahui pola hubungan sifat antara produksi dengan karakter kuantitatif. Namun menurut Genefianti et al. (2006) terdapat pengaruh tidak langsung melalui komponen hasil yang dapat lebih berperan daripada pengaruh langsung sehingga analisis korelasi tidak cukup untuk menjelaskan pola hubungan tersebut.

Tabel 6. Korelasi karakter agronomi dengan komponen hasil panen tua

\begin{tabular}{|c|c|c|c|c|c|c|c|c|c|c|c|c|c|c|}
\hline & US & UA & ASI & J & JG & $\mathrm{DB}$ & TTAN & TLP & TA & TG & PG & DG & JBB & BTB \\
\hline UA & $0,89: 8$ & & & & & & & & & & & & & \\
\hline ASI & $-0,15 \operatorname{tn}$ & 0,26 th & & & & & & & & & & & & \\
\hline лв & $0,41 \mathrm{tn}$ & 0,36 tn & 0,08 th & & & & & & & & & & & \\
\hline JG & $-0,03 \mathrm{tm}$ & 0,17 tn & $0,39 \mathrm{tm}$ & $0,08 \operatorname{tn}$ & & & & & & & & & & \\
\hline $\mathrm{DB}$ & $0,36 \operatorname{tn}$ & $0,28 \operatorname{tn}$ & 0,03 th & $0,29 \mathrm{tn}$ & $0,42 \mathrm{tn}$ & & & & & & & & & \\
\hline TTAN & $-0,05 \mathrm{tm}$ & 0,01 tn & 0,45 th & 0,44 th & $-0,04 \mathrm{tn}$ & 0,35 th & & & & & & & & \\
\hline TLP & $0,17 \operatorname{tn}$ & $0,18 \operatorname{tn}$ & $0,14 \mathrm{tn}$ & $-0,06 \mathrm{tn}$ & $-0,16 \operatorname{tn}$ & 0,01 tn & $-0,69 \mathrm{tn}$ & & & & & & & \\
\hline TA & $-0,32 \operatorname{tn}$ & $-0,45 \mathrm{tn}$ & $-0,43 \mathrm{tn}$ & $0,22 \mathrm{tm}$ & $-0,05$ th & 0,15 th & $0,14 \operatorname{tn}$ & $0,09 \mathrm{tm}$ & & & & & & \\
\hline TG & $-0,29 \mathrm{tn}$ & $-0,43 \mathrm{tm}$ & $-0,26 \mathrm{tn}$ & $-0,10 \mathrm{tn}$ & $-0,33 \mathrm{th}$ & $-0,01 \mathrm{tn}$ & $0,14 \operatorname{tn}$ & $0,68 *$ & $-0,21 \mathrm{tn}$ & & & & & \\
\hline PG & 0,34 th & 0,19 tn & $-0,30 \mathrm{tn}$ & $0,11 \mathrm{tn}$ & $-0,13 \mathrm{tn}$ & $-0,10 \mathrm{tn}$ & $-0,22 \mathrm{tn}$ & $-0,30 \mathrm{tn}$ & $-0,01 \mathrm{tm}$ & $-0,56^{*}$ & & & & \\
\hline DG & $0,64^{*}$ & 0,35 tn & $-0,71^{\mathbf{8 *}}$ & $0,31 \mathrm{tm}$ & $-0,18 \mathrm{tn}$ & $-0,04 \mathrm{tn}$ & $-0,49 \mathrm{tm}$ & $-0,40 \mathrm{tn}$ & 0,19 tn & $-0,53 \mathrm{th}$ & $0,68 * 8$ & & & \\
\hline JBB & $0,76^{* 8}$ & $0,38 \operatorname{tn}$ & $-0,72^{*}$ & 0,27 tn & $-0,48 \operatorname{tn}$ & $0,15 \mathrm{tn}$ & $-0,32 \mathrm{tn}$ & $-0,30 \mathrm{tn}$ & $-0,12 \mathrm{tn}$ & $-0,37 \mathrm{th}$ & $0,60 \mathrm{tn}$ & $0,60 * 8$ & & \\
\hline BTB & $0,43 \mathrm{tm}$ & $0,07 \mathrm{tm}$ & $-0,71^{* *}$ & $0,15 \mathrm{tm}$ & $-0,35 \mathrm{tn}$ & $-0,15 \mathrm{tn}$ & $-0,43 \mathrm{th}$ & $-0,22 \mathrm{tn}$ & $0,28 \mathrm{tm}$ & $-0,29 \mathrm{tn}$ & 0,7988 & $0,85 * 8$ & $0,83 * 8$ & \\
\hline BTK & $0,66^{* 8}$ & $-0,11 \mathrm{tm}$ & $-0,52 \operatorname{tn}$ & $0,02 \operatorname{tn}$ & $-0,03 \mathrm{tn}$ & $-0,40 \mathrm{tn}$ & $-0,59 *$ & $0,08 \mathrm{tn}$ & 0,37 th & $-0,23 \mathrm{tm}$ & $0,35 \operatorname{tn}$ & $0,68^{\circ}$ & $0,73 \approx 8$ & $0,63^{*}$ \\
\hline
\end{tabular}

Keterangan: $*=$ berpengaruh nyata pada taraf uji $\mathrm{P} \leq 0,05 ; * *=$ nyata pada taraf uji $\mathrm{P} \leq 0,01$; th $=$ tidak nyata pada taraf uji $\mathrm{P} \leq 0,05$ dan $\mathrm{P} \leq 0,01$. UA = umur berbunga jantan, US = umur berbunga betina, ASI = anthesis silking interval, $\mathrm{JB}=$ jumlah buku, $\mathrm{JG}=$ jumlah tongkol, $\mathrm{DB}=$ diameter batang, TLP $=$ tongkol layak pasar, $\mathrm{TA}=$ tongkol afkir, $\mathrm{PG}=$ panjang tongkol, $\mathrm{DG}=$ diameter tongkol, $\mathrm{JBB}=$ jumlah baris biji, $\mathrm{BTB}=$ bobot tongkol berkelobot, BTK = bobot tongkol tanpa kelobot, TG = tinggi tongkol utama, TTAN = tinggi tanaman.

\section{KESIMPULAN}

Genotipe-genotipe uji jagung ketan memiliki beberapa karakter kuantitatif dan kualitatif yang berbeda dari genotipe-genotipe uji yang lain maupun varietas pembanding URI. Sebanyak tujuh karakter yang diamati memiliki nilai heritabilitas arti luas $\left(\mathrm{h}^{2} \mathrm{bs}\right)$ yang tinggi dan satu karakter memiliki nilai heritabilitas arti luas $\left(\mathrm{h}_{\mathrm{bs}}^{2}\right)$ yang sedang. Karakter anthesis silking interval memiliki nilai koefisien keragaman dan heritabilitas arti luas yang tinggi serta berkorelasi nyata dengan komponen hasil berupa diameter tongkol, jumlah baris biji, dan bobot tongkol berkelobot sehingga dapat dipertimbangkan sebagai kriteria seleksi. Genotipe JLP1-2, JWP12- 5, dan JWP12-8 memiliki potensi sifat prolifik dengan jumlah tongkol per tanaman masing-masing sebanyak 2,55 tongkol, 2,20 tongkol, dan 2,31 tongkol. Genotipe SD2, JWP12-5， JWP12-3， JWP22-1， dan JLP1-6 memiliki karakter agronomi dan komponen hasil yang baik. 


\section{DAFTAR PUSTAKA}

Adriani, A., M. Azrai, W.B. Suwarno, S.H. Sutjahjo. 2015. Pendugaan keragaman genetik dan heritabilitas jagung hibrida silang puncak pada perlakuan cekaman kekeringan. Informatika Pertanian. 1(24):91- 100.

Anderson, S.R., M.J. Laeur, J.B. Schoper, R.M. Shibles. 2004. Pollination timing effects on kernel set and silk receptivity in four maize hybrids. Crop Sci. 44: 464-437.

Azrai, M., M.J. Mejaya, M.H.G. Yasin. 2007. Pemuliaan Jagung Khusus dalam Jagung Tehnik Produksi dan Pengembangan. Pusat Penelitian dan Pengembangan Tanaman Pangan, Maros.

Berger, Y. 1962. Maize Production and The Manuring of Maize. Centre d'Etude de I'Azote, New Zealand.

Brewbaker, J.L. 2003. Corn Production in the Tropics. College of Tropical Agriculture and Human Resources, Manoa.

Brisco, G. 2000. CODEX standard for baby corn. http://cxs.babycorn.com. [20 Desember 2016]. Brucher H. 1989. Useful Plants of Neotropical Origin and Their Wild Relative. Springer-verlag, Berlin.

Chafid, M., R. Widianingsih, Noviati., B. Waryanto, L. Nuryati, Suwandi., Tarmat., Victor. 2015. Outlook Komoditas Pertanian Tanaman Pangan Jagung. Pusat Data dan Sistem Informasi Pertanian Kementerian Pertanian, Jakarta.

Creech, R.G. 1965. Genetic control of carbohydrate synhesis in mize endosperm. Geneics. 52 : 1175-1186. Dewanti D., Basunanda P., dan Purwantoro A. 2015. Variabilitas karakter fenotipe dua populasi jagung manis (Zea mays L. Kelompok Saccharata). Vegetalika. 4(4):35-47.

Edmeades, G.O., H R. Lafitte. 1993. Defoliation and plant density effects on maize selected for reduced plant height. Agronomy Journal 85(4):850-857.

Genefianti, Y. Dwi, Yulian, A.N. Suprapti. 2006. Korelasi dan sidik lintas antara pertumbuhan, komponen hasil, dan hasil dengan gugur buah pada tanaman cabai. Jurnal Akta Agrios. 9(1): 1-6.
Gomez, K.A., A.A. Gomez. 1995. Prosedur statistik untuk Penelitian Pertanian. Sjamsudin E., Justika S.B., penerjemah. UI Press, Jakarta. Terjemahan dari: Statistical Procedures for Agricultural Research.

Hallauer, A.R., M.J. Carena, J.B.M. Filho. 2010. Quantitative genetics in maize breeding. Volume ke-6. New York (US): Springer.

[IBPGR] International Board for Plant Genetic Resource. 1991. Descriptors for Maize. IBPGR, Roma.

[Kementan] Kementerian Pertanian. 2015. Konsumsi rata-rata per kapita beberapa bahan makanan di Indonesia 2009-2013. [Internet] [diunduh 2016 Oktober 17] tersedia pada http : // www . pertanian . go . id / Indikator / tabe - 15b - konsumsi - rata . pdf

Kopyra, A.K., A. Szmigiel, T. Zajac, and A. Kiadacka. 2012. Some aspect of cultivation and utilization of waxy maize (Zea mays L. spp. ceratina). Acta Agrobotanica 65(3): 3-12.

Mattjik, A.A., Sumertajaya. 2006. Perancangan Percobaan Jilid 1 Edisi ke-2. IPB Press, Bogor.

Mendez-Natera, J.R., A. Rondon, J. Hernandes, J.F. Merazo Pinto. 2012. Genetic studies in upland cotton. III. genetik parameters, correlation and path analysis. SABRAO Journal of Breeding dan Genetics. 44(1):112-128.

Murni, A.M., R.W. Arief, B. Irawan, Kiswanto., B. Wijayanto, Hermanto, T. Kusnanto. 2008. Teknologi Budidaya Jagung. Balai Besar Pengkajian dan Pengembangan Teknologi Pertanian, Bogor.

Moedjiono, M.J. Mejaya. 1994. Variabilitas Genetik Plasma Nutfah Jagung Koleksi Balittan Malang. Zuriat 5(2) : 27-32.

Poehlman, J.M., D. Borthakur. 1969. Breeding Asian Field Crops with Special Reference to Crops of India. Oxford \& IBH, New Delhi.

Rahmawati, D., T. Yudistira, S. Mukhlis. 2014. Uji inbreeding depression terhadap karakter fenotipe tanaman jagung manis (Zea mays var. Saccharata Sturt) hasil selfing dan open pollinated. Jurnal Ilmiah INOVASI 14 (2) : 145-155. 
Sari, N.P. 2015. Evaluasi karakter agronomi beberapa genotipe jagung lokal dan galurgalur pemuliaan sebagai jagung semi. Skripsi. Institut Pertanian Bogor. Bogor.

Simla, S., K. Lertrat, B. Suriharn 2009. Gene effects of sugar compositions in waxy corn. Asian J.Plant Sci 1(1) : 1-8.

Sirajuddin, N. 2014. Keragaan genotipe jagung pulut manis terseleksi hasil dari persilangan antara galur jagung pulut dengan varietas jagung pulut manis komersial. Skripsi. Universitas Hasanuddin. Makassar.

Suarni, dan Yasin. 2011. Jagung sebagai pangan fungsional. Iptek Tanaman Pangan 6(1) : 41-56.

Subekti, N.A., Syafruddin., R. Efendi, S. Sunarti S. 2007. Morfologi Tanaman dan Fase Pertumbuhan Jagung. Balai Penelitian Tanaman Serealia, Maros.

Syukur, M., S. Sujiprihati, R. Yunianti 2012. Teknik Pemuliaan Tanaman. Penebar Swadaya, Jakarta. Szymanek M., Dobrzaski jr B., Niedziolka I. and Rybczynski R. 2006. Sweet Corn Harvest and Technology Physical Properties and quality. B. Dobrzański Institute of Agrophysicsof Polish Academy of Sciences, Poland.

Umar, S. 2012. Pengaruh Pemberian Bahan Organik terhadap Daya Simpan Benih Kedelai(Glycine max (L.) Merr.). Berita Biologi. 11(3):401-410.
Wicaksana, N. 2001. Penampilan fenotipik dan beberapa parameter genetik 16 genotipe kentang pada lahan sawah. Zuriat12(1):15-20.

Worrajinda, J., K. Lertrat, B. Suriharn. 2013. Combining ability of super sweet corn inbred lines with different ear sizes for ear number and whole ear weight. SABRAO Journal of Breeding and Genetics. 45 (3): 468-477.

Yasin, H.G.M., Sumarno, A. Nur. 2014. Perakitan varietas unggul jagung fungsional. Pusat Pengembangan Tanaman Pangan, Nogor.

Yudiwanti, S.G. Budiarti, dan Wakhyono. 2006. Potensi jagung varietas lokal sebagai jagung semi. Prosiding Seminar Nasional Bioteknologi dan Pemuliaan Tanaman [internet]. [Bogor, 1-2 Agustus 2006]. Bogor (ID):IPB.Hlm 376-379; [diunduh 2017 Juli 18]. Tersedia pada: http : // www .agrohort .ipb .ac. id/ downloads / jagung_semi\%20_potensi_jagung_lokal\% 202007.pdf.

Yusran dan Maemunah. 2011. Karakterisasi morfologi varietas jagung ketan di Kecamatan Ampana Kota Kabupaten Tojo Una-Una. J. Agroland 18 (1) : 36-42.

Zsubori, Z., Z. Gyenes, Hegyi, O. Illes, I. Pok, F. Racz, C. Szoke. 2002. Inheritance of plant and ear height in maize (Zea mays L.). Acta Agraria [internet]. [diunduh $2017 \quad 30 \quad$ Juli]. Tersedia pada: www.date.hu/acta-agraria/200208i/zsubori.pdf 